\title{
KONSTRUKSI BERITA LAYANAN PUBLIK DALAM PROGRAM "SUMUT DALAM BERITA" TVRI SUMATERA UTARA
}

\author{
Feby Grace Adriany \\ Magister Ilmu Komunikasi Fakultas Ilmu Sosial dan Ilmu Politik \\ Universitas Sumatera Utara \\ Jl. Dr. A. Sofyan No 1, Kampus USU Medan 20155 Telp. 0618213236 \\ Email : febygrace@gmail.com
}

\begin{abstract}
This research is conducted to determine the construction of public service news in 'Sumut Dalam Berita' program aired on TVRI North Sumatera. With the phenomenological approach, this research used a Theories of Influences on Mass Media Content by Pamela J. Shoemaker and Stephen D. Reese. A study conducted an in-depth interview with an internal level of TVRI North Sumatera that is managerial level and the external party who cooperate with TVRI that is North Sumatera Provincial Government. The results showed that : (1) public service news is being a part of the cooperation between TVRI North Sumatera and the Provincial Government. TVRI also receive funds from local budgets for operations activities, (2) each level of the influence of media content starting from individual level to ideological level contributes to public service news production in 'Sumut Dalam Berita.' Sometimes there are overlaps between the ideal and practical concepts experienced by the journalist in delivering public information to the public. The contribution of this research is to give insight to journalists and editors on how to produce news, especially on public services without ignoring news value.
\end{abstract}

Keyword: News Construction, Public Broadcasting, Sumut Dalam Berita

\begin{abstract}
Abstrak
Penelitian ini bertujuan mengetahui konstruksi berita layanan publik dalam program Sumut Dalam Berita yang ditayangkan TVRI Sumatera Utara. Penelitian dengan pendekatan fenomenologi ini menggunakan Theories of Influences on Mass Media Content yang dikemukakan Pamela J. Shoemaker dan Stephen D. Reese. Studi melakukan wawancara mendalam terhadap pihak internal TVRI Sumatera Utara yakni bagian manajerial dan pihak eksternal yakni pihak yang bekerjasama dengan TVRI yaitu Pemerintah Propinsi Sumatera Utara. Hasil penelitian menunjukkan bahwa (1) berita layanan publik menjadi bagian dari kerjasama TVRI Sumatera Utara dengan Pemerintah Propinsi Sumatera Utara. Dalam hal ini TVRI Sumatera Utara juga mendapatkan dana APBD untuk membantu operasional penyiaran, (2) setiap tingkatan pengaruh isi media mulai dari level individual hingga ideologi memberikan andil terhadap produksi berita layanan publik dalam 'Sumut Dalam Berita'. Tak jarang terjadi tumpang tindih antara konsep ideal dan praktis dialami jurnalis TVRI Sumatera Utara dalam menghadirkan informasi publik kepada masyarakat. Kontribusi penelitian ini adalah memberikan wawasan kepada wartawan ataupun redaksi bagaimana seharusnya membuat berita khusunya mengenai layanan publik tanpa mengesampingkan nilai berita.
\end{abstract}

Kata kunci : Konstruksi Berita, Penyiaran Publik, Sumut Dalam Berita

\section{Pendahuluan}

Mediamassa saatini memilikiperan yang sangat penting bagi pemenuhan informasi kepada masyarakat. Dari banyaknya pilihan media massa yang ada, media massa televisi nampaknya masih menjadi primadona dengan kekuatan audio visualnya. Stasiun televisi berlomba-lomba merebut hati pe- mirsanya dengan menciptakan program yang memenuhi kebutuhan pemirsa akan informasi, terutama lewat tayangan berita.

Salah satu pertanyaan penting yang perlu ditelaah lebih jauh adalah informasi seperti apa yang didistribusikan oleh media massa kepada masyarakat. Pada kenyataannya tidak semua informasi yang disebarkan 
oleh media massa, termasuk televisi melalui program beritanya, merupakan informasi yang dibutuhkan oleh masyarakat. Televisi Republik Indonesia (TVRI) merupakan satu-satunya televisi publik di negara ini dan dengan peran ini tentu TVRI memiliki beban dan tanggung jawab yang berbeda dengan televisi lainnya dalam menyebarkan informasi kepada masyarakat.

TVRI sebagai televisi publik juga memiliki rangkaian siaran berita yang ditayangkan secara reguler baik secara nasional maupun siaran berjaringan yang dilakukan oleh stasiun-stasiun lokal TVRI di masing-masing propinsi. Program-program berita ini memiliki nama yang berbedabeda pada setiap propinsi, misalnya 'Sumut Dalam Berita', 'Jambi Dalam Berita' dan 'Warta Bali'. Program berita ini menjadi bagian dari siaran lokal yang keseluruhannya mengudara selama 4 jam dalam sehari mulai pukul 15.00 sampai dengan 19.00 waktu setempat.

Hasil riset yang dilakukan oleh TVRI Sumatera Utara bersama Departemen Ilmu Komunikasi Universitas Sumatera Utara tahun 2013 menyebutkan bahwa program berita harian di TVRI Sumatera Utara yaitu Sumut Dalam Berita (SDB) menjadi tayangan yang paling banyak diketahui dan disukai penonton dari seluruh program acara TVRI Sumatera Utara. SDB ditayangkan selama 60 menit dengan mengangkat berita-berita lokal di Sumatera Utara. Namun bila dibandingkan dengan tayangan yang disiarkan televisi lain pada jam yang sama, posisi SDB masih sangat lemah (Riset Penonton dan Program TVRI Sumatera Utara, 2013).
Program SDB setiapharinyamenayangkan 21-28 item berita dengan durasi normal masing-masing berkisar 1 menit 30 detik. Terdapat pembagian segmen dalam tayangan SDB berdasarkan jenis dan isi berita, salah satunya adalah segmen Klasifikasi Seremonial yang berisi berita-berita hasil kerjasama TVRI dengan Pemerintah Propinsi Sumatera Utara dan Pemerintah Kota Medan serta berita seremonial lainnya.

Berdasarkan perjanjian kerjasama dengan Pemerintah Propinsi Sumatera Utara, TVRI Sumatera Utara wajib menyediakan slot waktu penyiaran untuk sejumlah program acara, baik program berita maupun non-berita seperti misalnya dialog interaktif, program keagamaan dan lain-lain. Kerjasama ini bernilai Rp. 593.800.000,- untuk tahun 2016.

Terkait kewajiban TVRI khusus untuk tayangan SDB, kru TVRI wajib meliput dan menyiarkan kegiatan harian Pemerintah Propinsi Sumatera Utara yang dilakukan oleh Gubernur Sumatera Utara, Wakil Gubernur Sumatera Utara, Sekretaris Daerah Propinsi Sumatera Utara beserta perangkat Pemerintah Propinsi Sumatera Utara (Dinas, Badan dan SKPD jajaran Pemerintah Propinsi Sumatera Utara), DPRD Propinsi Sumatera Utara dan Dharma Wanita. Jumlah seluruh paket berita yang disepakati adalah 310 tayangan untuk tahun 2016 dengan total anggaran yang diberikan untuk berita harian sebesar Rp. 155.000.000,-. Berdasarkan angka ini, maka untuk setiap berita kegiatan Pemerintah Daerah Propinsi Sumatera Utara yang disiarkan mendapat dana Rp. 500.000,-.

Mayoritas isi berita kerjasama dalam segmen Klasifikasi Seremonial tersebut 
bersifat seremonial kegiatan harian Walikota Medan dan Gubernur Sumatera Utara. Mengingat keberadaan TVRI sebagai lembaga penyiaran publik, tentu nilai berita dari sebuah peristiwa yang disiarkan dalam SDB TVRI Sumatera Utara harus berkaitan dengan kepentingan publik Sumatera Utara. Pada prakteknya tidak semua aktivitas harian Kepala Daerah yang disiarkan TVRI memiliki bobot nilai yang sama pentingnya bagi publik dimana idealnya berita-berita tersebut menjadi berita yang sarat dengan kegiatan layanan publik yang dilakukan oleh pemerintah daerah.

Sebagai lembaga penyiaran publik, seluruh rancangan program TVRI Sumatera Utara serta kandungan isi program acara haruslah berorientasi pada kepentingan khalayaknya untuk mendapatkan informasi (right to know) dan hak untuk menyatakan pendapat (right to express). Lembaga model ini mempunyai visi untuk memperbaiki kualitas kehidupan publik, kualitas kehidupan suatu bangsa dan juga kualitas hubungan antarbangsa pada umumnya, serta mempunyai misi untuk menjadi forum diskusi, artikulasi dan pelayanan kebutuhan publik.

Tanggung jawab lembaga penyiaran publik tentu lebih berat karena sifatnya yang independen dari kepentingan negara dan kepentingan komersial, serta pembiayaan yang dibebankan kepada pengguna, dalam hal ini TVRI menggunakan Anggaran Pendapatan dan Belanja Nasional (APBN) dan Anggaran Pendapatan dan Belanja Daerah (APBD). Terlebih lagi dengan mengacu pada sejumlah kriteria nilai berita yang tepat, maka rancangan isi program SDB pun haruslah mampu menjawab kebutuhan publik Sumatera Utara akan informasi.

Saat ini sejumlah program berita pada beberapa stasiun televisi swasta kerap mendapat tudingan tidak bebas nilai dan berpihak pada kepentingan ekonomi politik kelompok tertentu, lembaga penyiaran publik harus hadir sebagai penyedia informasi alternatif bagi khalayak. Tanggungjawab akan visi tayangan lembaga penyiaran publik yang bersiaran secara lokal ini tentulah harus direncanakan dengan baik dan matang.

Direktur Eksekutif The Independent Television Commission (ITC) Richard Eyre mengatakan 'Free school doesn't work when the kids go and buy Coca-Cola because it's available and they prefer it and they can afford it. So public service broadcasting will soon be dead' (Weeds, 2013). Artinya lembaga penyiaran publik menghadapi dua tantangan besar jika ingin mencapai tujuannya. Pertama, program siaran yang dirancang haruslah mendekati masyarakat sebagai khalayak, sehingga masyarakat akan memilih menyaksikan tayangan lembaga penyiaran publik daripada tayangan lain. Kedua, mengingat besarnya jumlah masyarakat yang beralih ke media baru (internet) untuk memperoleh informasi dan hiburan, lembaga penyiaran publik haruslah mengikuti tren tersebut jika tak ingin ditinggalkan.

Hasil survei indeks kualitas program siaran televisi yang dilakukan oleh Komisi Penyiaran Indonesia (KPI) pada NovemberDesember 2015 untuk siaran berita tanah air secara umum masih menunjukkan angka di bawah standar yang ditetapkan oleh KPI yaitu 4 (www.kpi.go.id). 


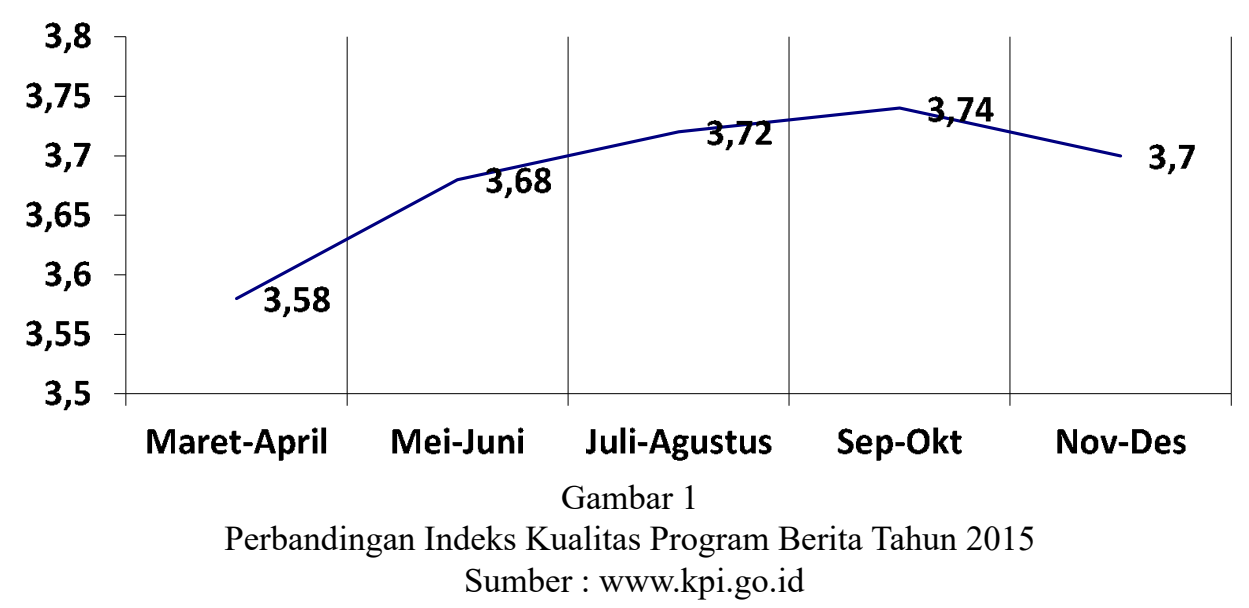

Ruang redaksi sebagai 'otak' dari segala aktivitas jurnalisme tentu memiliki kebijakan untuk mengatasi dan mengantisipasi segala keterbatasan TVRI dalam hal pemberitaan, terutama tarik-menarik berbagai kepentingan yang dapat mempengaruhi kerja jurnalistiknya. Meskipun sebuah karya jurnalistik merupakan karya tim peliputan yang terdiri dari reporter dan juru kamera, namun hasil akhir hingga berita disiarkan harus melalui proses pengolahan yang merupakan kerja kolektif keredaksian. Baik reporter, redaktur, hingga TVRI secara organisasi tentu memberi andil dalam membentuk setiap berita yang akhirnya disiarkan kepada masyarakat.

TVRI sendiri juga memiliki seperangkat kebijakan terkait keberadaannya sebagai lembaga penyiaran publik yang disusun oleh Dewan Pengawas TVRI. Berdasarkan ketentuan isi siaran, pembuatan program siaran baik untuk siaran lokal, nasional, regional maupun siaran internasional, TVRI harus berdasarkan (LPP TVRI, 2012: 20) : 1) pembuatan program siaran wajib memperhatikan aspek-aspek sosial, budaya dan kepublikan dari setiap program acara siaran; 2) pembuatan program siaran wajib memperhatikan faktor sensitivitas terhadap isu SARA dan potensi konflik, sekaligus melindungi dan memajukan hak asasi manusia, kesejahteraan dan kedamaian yang mendasarkan pada kearifan lokal dalam rangka mendorong solidaritas dan memperkuat modal sosial; 3) pembuatan program siaran didasarkan pada hasil riset penonton atau pengguna layanan dan segmentasi program siaran atau layanan; 4) pembuatan program wajib memperhatikan faktorfaktor kompetisi televisi dan/atau teknologi informasi meliputi isi siaran (program content), waktu tayang (program layout), struktur acara (program structure), kemasan acara (program montage), promosi acara (program promotion), kualitas audio-video serta perkembangan teknologi.

Secara lebih khusus, kebijakan TVRI sebagai lembaga penyiaran publik juga mengatur masalah muatan atau isi siaran (LPP TVRI, 2012:21)yaitu:1)mempertimbangkan faktor-faktor budaya, norma, nilai-nilai dan mencerminkan terwujudnya nilai-nilai demokrasi, untuk dapat diambil manfaat sebesar-besarnya bagi kepentingan publik dalam kerangka menciptakan ketahanan budaya; 2) menggunakan etika profesi dan standar mutu tinggi sesuai dengan 
prinsip penyiaran publik; 3) memproduksi dan menyiarkan berita yang aktual dan akurat dengan mengedepankan kebenaran dan menjunjung tinggi objektivitas; 4) mencerminkan eksplorasi dan keberagaman budaya lokal sebagai bagian dari kekayaan kebudayaan nasional; 5) memberikan ruang dan kesempatan yang sama kepada seluruh lapisan dan golongan masyarakat, termasuk kelompok masyarakat di daerah tertinggal (terisolir); 6) menyediakan akses penyiaran secara interaktif bagi publik termasuk mengembangkan citizen journalism; 7) mengembangkan siaran-siaran pendidikan, seni dan budaya, olahraga serta siaran khusus berdasarkan segmen-segmen pemirsa seperti anak-anak, remaja dan manula serta perempuan terkait dengan pengarusutamaan gender; 8) mewujudkan rasa optimisme dan cinta tanah air serta meningkatkan citra positif bangsa Indonesia di tingkat internasional.

Dapat dikatakan TVRI Sumatera Utara berada pada posisi dilematis dalam melakukan penyiaran berita layanan publik ini. Satu sisi, TVRI Sumatera Utara harus menjaga independensinya dalam memberitakan sebuah peristiwa berdasarkan nilai berita yang sesuai, namun di sisi lain kerjasama dengan pemerintah daerah ini seakan mengikat TVRI Sumatera Utara untuk menyiarkan aktivitas harian kepala daerah atas dasar kompensasi dana yang dibayarkan pemerintah daerah. Penelitian ini mencoba melihat bagaimana redaksi Sumut Dalam Berita melakukan konstruksi berita layanan publik dilihat dari 5 tingkatan pengaruh isi media oleh Pamela J. Shoemaker dan Stephen D. Reese.
Pada bukunya The Message: Theories of Influences on Mass media Content (1996) disebutkan terdapat sejumlah tingkatan faktor yang mempengaruhi pengambilan keputusan di ruang redaksi dalam menentukan isi media, yaitu level individual, level rutinitas media, level organisasi, level ekstramedia dan level ideologi (Shoemaker \& Reese, 1996: 60).

Pada level individual pekerja media terdapat sejumlah hal yang setidaknya dapat mempengaruhi isi media, yaitu : 1) karakteristik, latar belakang personal dan pengalaman komunikator; 2) latar belakang profesi dan pengalaman komunikator; 3) aturan dan etika profesional komunikator; 4) sikap, nilai, kepercayaan (agama) komunikator; 5) kekuatan komunikator dalam organisasi media; dan 6) efek dari karakteristik latar belakang, pengalaman, sikap, nilai, agama, aturan, etika dan kekuasaan komunikator dalam isi media (Shoemaker \& Reese, 1996: 72).

Sementara pada tingkatan rutinitas media, ada tiga sumber utama rutinitas yang menjadi semacam paksaan bagi media dalam menyusun kontennya. Pertama, orientasi kepada audiens media misalnya dalam

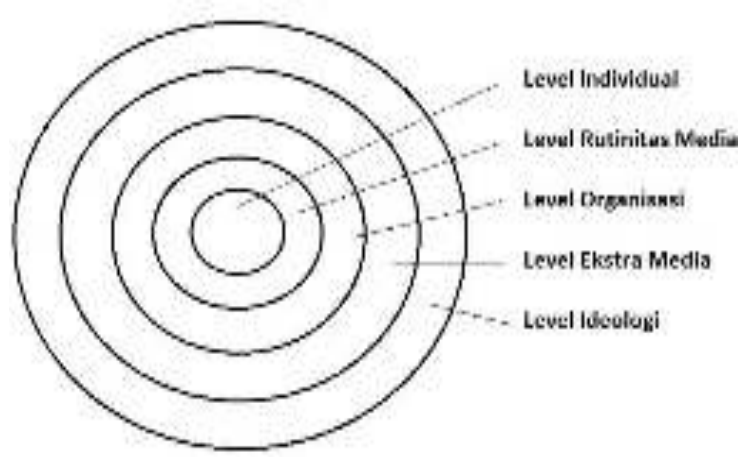

Gambar 2

Theories of Influences on Mass Media Content Sumber : Shoemaker \& Reese, 1996. 
hal nilai berita yang disusun berdasarkan peristiwa mana yang paling menarik perhatian audiens. Kedua, organisasi media sebagai pemroses informasi (prosesor). Dalam redaksi telah terbangun sistem kerja yang menjadi standar dan dipahami oleh semua anggota misalnya sistem tenggat waktu (deadline) dan sistem pengkategorian berita. Ketiga, sumber informasi eksternal yang biasanya memberikan informasi kepada media baik dalam bentuk wawancara, laporan perusahaan dan data-data lain. Media cukup bergantung pada narasumber-narasumber semacam ini terutama untuk peristiwa-peristiwa penting (Shoemaker \& Reese, 1996: 105-123).

Tingkatan ketiga adalah pengaruh yang diberikan oleh organisasi media misalnya struktur organisasi media bahkan hingga tingkat kepemilikan media. Kepemilikan pun akan berimbas pada orientasi media dimana sebagian media ingin menghasilkan keuntungan namun sebagian lainnya ingin menghasilkan karya berkualitas, mendapatkan pengakuan secara profesional atau melayani kebutuhan publik.

Tingkatan keempat adalah faktor-faktor di luar media yang mempengaruhi konten media massa. Faktor-faktor tersebut antara lain sumber informasi atau narasumber media seperti misalnya kelompok-kelompok kepentingan khusus dan kampanye humas. Selain itu, sumber pemasukan finansial media massa juga memberi pengaruh seperti pengiklan, audiens, institusi bisnis, pemerintah, lingkungan ekonomi dan teknologi (Shoemaker \& Reese, 1996 : 172).

Tingkatan kelima adalah level ideologi. Pada level ini akan timbul pertanyaan kepentingan siapa yang terkait dengan rutinitas dan kerja media massa, kekuasaan dalam masyarakat dan bagaimana kekuasaan tersebut berperan dalam media massa (Shoemaker \& Reese, 1996: 215).

Pada lembaga penyiaran publik, konstruksi ini menjadi sangat penting mengingat informasi yang disampaikan TVRI melalui tayangan berita idealnya menjadi rujukan kebenaran bagi publik Sumatera Utara. Keberadaan TVRI sebagai televisi publik pun tak dapat dibandingkan dengan televisi swasta mengingat peran dan tanggungjawab yang berbeda.

McQuail (2010: 178) mendefinisikan lembaga penyiaran publik mengacu pada sistem penyiaran yang didirikan berdasarkan hukum dan biasanya didanai oleh publik, memberikan keleluasaan pada operasional dan keredaksiannya namun harus melayani kebutuhan publik. Penyiaran publik hadir sebagai alternatif untuk memecahkan persoalan dikotomi antara negara dan modal.

Pada dasarnya tidak ada teori yang berlaku umum terkait penyiaran publik. Setidaknya tujuan penyiaran publik selalu dikaitkan dengan kepentingan publik (McQuail, 2010) antara lain : 1) universality of geographic coverage, artinya jangkauan siaran dapat diterima publik dalam wilayah geografi yang luas; 2) diversity in providing for all main tastes, interests and needs as well as matching the full range of opinions and benefits, artinya konten siaran memiliki keberagaman yang dapat memenuhi banyak kepentingan, tidak hanya menyediakan informasi bagi segelintir pihak saja; 3) providing for special minorities, 
artinya memberikan perhatian yang cukup pada kepentingan kelompok minoritas dalam masyarakat; 4) having concern for the national culture, language and identity, artinya penyiaran mengutamakan kebudayaan nasional, bahasa dan identitas nasional; 5) serving the needs of the political system, artinya konten siaran diharapkan mampu memenuhi dan menunjang sistem politik yang berlaku; 6) providing balanced and impartial information on issues of conflict, artinya prinsip netralitas diutamakan, seimbang dan tidak memihak dalam menyoroti isu dan konflik; 7) having a specific concern for 'quality' as defined in different ways, artinya kualitas menjadi perhatian utama dalam penyajian isi siaran; 8) putting public interest before financial objectives, artinya kepentingan publik diutamakan di atas kebutuhan finansial.

Berdasarkan latar belakang yang sudah dipaparkan, penelitian ini bertujuan mengetahui konstruksi berita layanan publik dalam program Sumut Dalam Berita yang ditayangkan TVRI Sumatera Utara.

\section{Metode Penelitian}

Penelitian ini merupakan penelitian kualitatif dengan perspektif fenomenologi. Fenomenologi berusaha untuk mengungkap dan mempelajari serta memahami suatu fenomena beserta konteksnya yang khas dan unik yang dialami oleh individu hingga tataran 'keyakinan' individu yang bersangkutan. Dengan demikian dalam mempelajari dan memahaminya, haruslah berdasarkan sudut pandang, paradigma dan keyakinan langsung dari individu yang bersangkutan sebagai subjek yang mengalami langsung.
Subjek penelitian ini dibagi menjadi dua yaitu informan utama dan informan tambahan. Informan utama adalah pihak yang membuat kebijakan di dalam TVRI Sumatera Utara khususnya dalam redaksi pemberitaan Sumut Dalam Berita yaitu : Kepala Stasiun TVRI Sumatera Utara, Kepala Bidang Pemberitaan TVRI Sumatera Utara dan Kepala Seksi Produksi Berita TVRI Sumatera Utara. Sedangkan informan tambahan berasal dari pihak eksternal TVRI Sumatera Utara yang menjalin kerjasama dengan TVRI yaitu Pemerintah Propinsi Sumatera Utara dalam hal ini diwakili oleh pihak Dinas Komunikasi dan Informatika Propinsi Sumatera Utara.

Pengumpulan data dilakukan dengan wawancara mendalam (indepth interview), observasi partisipan (participant observer), serta metode bahan visual. Tahapan analisis data induktif dilakukan dengan cara : 1) melakukan pengamatan terhadap fenomena sosial, melakukan identifikasi, revisi-revisi dan pengecekan ulang terhadap data yang ada; 2) melakukan kategorisasi terhadap informasi yang diperoleh; 3) menelusuri dan menjelaskan kategorisasi; 4) menjelaskan hubungan-hubungan kategorisasi; 5) menarik kesimpulan umum; dan 6) membangun atau menjelaskan teori.

Pengujian keabsahan hasil penelitian dilakukan dengan cara triangulasi data (Moleong, 2006: 330). Penelitian ini menggunakan dua langkah triangulasi sekaligus yakni triangulasi metode dan sumber data. Triangulasi pertama adalah triangulasi metode melalui pengecekan derajat kepercayaan penemuan hasil penelitian 
beberapa teknik pengumpulan data yaitu wawancara mendalam dan observasi. Sedangkan triangulasi kedua adalah triangulasi sumber yang membandingkan dan mengecek balik derajat kepercayaan suatu informasi yang diperoleh melalui waktu dan alat yang berbeda dalam penelitian.

\section{Hasil Penelitian dan Pembahasan}

Merujuk pada lima tingkatan pengaruh yang berpotensi menentukan isi media massa dalam hal ini Sumut Dalam Berita versi Shoemaker dan Reese, maka terkait level yang paling dalam yaitu faktor individual, informan sepakat bahwa latar belakang pendidikan dan pengalaman individu reporter sangat menentukan pemilihan isu serta gaya jurnalistik yang ditampilkan, bahkan tak jarang aspek agama ataupun kepercayaan yang dianut menentukan bagaimana pemilihan isu yang diliputnya.

Karakteristik ini menarik bila dikaitkan dengan cara perekrutan pegawai TVRI Sumatera Utara dimana sebagian besar adalah Pegawai Negeri Sipil yang sudah bekerja puluhan tahun di TVRI. Pada saat itu, tingkat pendidikan tinggi tidak menjadi syarat utama dalam mencari pekerja, sehingga cukup banyak pegawai TVRI yang direkrut dengan tingkat pendidikan Sekolah Menengah Atas, sebagian melanjutkan pendidikan tingginya sambil bekerja. Terlebih lagi dalam redaksi pemberitaan, tidak ada persyaratan mutlak yang mengharuskan para jurnalisnya merupakan lulusan sekolah jurnalistik atau komunikasi massa. TVRI memberikan pedidikan dan pelatihan kepada pekerjanya sesuai dengan tangungjawab pekerjaannya.
Footlick (dalam Shoemaker \& Reese, 1996: 72) mengatakan bahwa jurnalis yang baik harus 'sedikit tahu tentang banyak hal' artinya jurnalis dituntut untuk menguasai banyak pokok bahasan mulai dari kebijakan asing, politik, sejarah, ekonomi dan lain-lain. Ini merupakan kualitas fundamental yang diberikan institusi pendidikan tinggi khususnya komunikasi massa. Tak heran banyak perusahaan media massa yang memaksa para jurnalisnya untuk mengambil kelas lanjutan mengenai subjek-subjek tertentu. Shoemaker melalui penelitiannya menemukan bahwa pendidikan dasar komunikasi massa dirancang untuk mempersiapkan jurnalis menjadi insiders dan oursiders yang kritis terhadap berbagai institusi sosial termasuk juga media massa. Pada akhirnya pendidikan menentukan bagaimana cara seorang reporter memandang dunia dan menggali kedalamannya.

Sementara itu karakteristik kepercayaan yang dianut reporter setidaknya menunjukkan bias dalam penulisan berita. Shoemaker \& Reese (1996: 254) mengatakan bahwa orangorang yang memiliki kesamaan dengan jurnalis akan ditampilkan secara berbeda dengan orang-orang yang tidak memiliki kesamaan. Hal ini merujuk pada karakteristik demografis reporter seperti misalnya jenis kelamin, etnis, orientasi seksual dan lain-lain. Reporter perempuan akan menghasilkan tulisan yang berbeda mengenai isu perempuan bila dibandingkan dengan reporter pria, begitupun dengan karakteristik lain yang mempengaruhi bagaimana sebuah isu dibingkai.

Terkait dengan hal ini, TVRI Sumatera Utara memiliki reporter dan juru kamera khusus untuk melakukan peliputan kegiatan 
pemerintah daerah. Setiap harinya tim peliputan ini akan mengikuti agenda kegiatan harian kepala daerah dan menulis hasil liputannya untuk ditayangkan. Reporter tersebut diberi kebebasan untuk menentukan sendiri sudut pandang beritanya tanpa perlu diarahkan oleh editor yang bertugas pada hari itu. Mayoritas berita yang dihasilkan adalah gambaran umum acara yang diikuti oleh kepala daerah tersebut, menulis ulang rilis yang dibagikan saat acara atau menulis sebagian kutipan hasil wawancara sebagai naskah. Peneliti menemukan bahwa tidak ada eksplorasi mendalam terhadap permasalahan layanan publik yang diangkat menjadi berita atau bahkan lebih jauh mengkritisi dan memanfaatkan momen kepala daerah tersebut menjawab secara jelas permasalahan layanan publik yang ada di Sumatera Utara.

Undang-undang No 25 Tahun 2009 tentang Pelayanan Publik menyebutkan bahwa yang dimaksud dengan pelayanan publik adalah kegiatan atau rangkaian kegiatan dalam rangka pemenuhan kebutuhan pelayanan sesuai dengan peraturan perundang-undangan bagi setiap warga negara dan penduduk atas barang, jasa, dan/atau pelayanan administratif yang disediakan oleh penyelenggara pelayanan publik. Pelayanan publik diselenggarakan oleh institusi penyelenggara negara, korporasi, lembaga independen yang dibentuk berdasarkan undang-undang untuk kegiatan pelayanan publik dan badan hukum lain yang dibentuk semata-mata untuk kegiatan pelayanan publik. Banyak bidang layanan publik yang seharusnya dapat digali oleh jurnalis TVRI Sumatera Utara sehingga hasil liputannya menjawab beragam permasalahan layanan publik yang dihadapi masyarakat Sumatera Utara.

Jurnalis TVRI Sumatera Utara dalam hal ini kurang menunjukkan pengetahuan dan kompetensinya sebagai jurnalis sehingga dapat menghasilkan konten berita yang berkualitas dan mendalam. Hal ini diduga erat berkaitan dengan tingkat pendidikan jurnalis itu sendiri. Di satu sisi, permasalahan tingkat pendidikan memang tidak menjadi masalah mengingat belum ada peraturan resmi yang mengharuskan jurnalis berpendidikan minimal Strata 1 .

Pada Peraturan Dewan Pers No.1/ Peraturan-DP/II/2010 tentang Standar Kompetensi Wartawan, dituliskan bahwa kompetensi wartawan pertama-tama berkaitan dengan kemampuan intelektual dan pengetahuan umum. Kompetesi wartawan yang dimaksud adalah kemampuan memahami etika dan hukum pers, konsepsi berita, penyusunan dan penyuntingan berita serta bahasa. Hal yang terakhir juga menyangkut kemahiran melakukannya, seperti juga kemampuan yang bersifat teknis sebagai wartawan profesional, yaitu mencari, memperoleh, menyimpan, memiliki, mengolah serta membuat dan menyiarkan berita. Berdasarkan hal tersebutlah maka para jurnalis atau wartawan diwajibkan mengikuti ujian kompetensi yang dilakukan oleh lembaga yang telah diverifikasi Dewan Pers, yaitu perusahaan pers, organisasi wartawan, perguruan tinggi atau lembaga pendidikan jurnalistik.

Sementara itu terkait tingkatan berikutnya yaitu level rutinitas media, seluruh informan 
utama menyatakan bahwa faktor rutinitas memberi pengaruh cukup besar terhadap isi siaran SDB. Rutinitas yang sudah terbentuk bertahun-tahun dengan pekerja yang sebagian besar merupakan pekerja lama, membentuk sebuah sistem yang diterima oleh seluruh anggota redaksi. Sistem inilah yang membuat aktivitas di dalam redaksi berjalan otomatis setiap harinya. Pihak manajemen redaksi tidak perlu melakukan arahan yang detail ataupun pengawasan yang ketat karena reporter, kameramen, desk editor dan anggota redaksi lainnya dianggap sudah memahami apa pekerjaan pokoknya. Aspek kebenaran dan ketepatan dalam melakukan pekerjaan bukan lagi menjadi yang utama, melainkan melanjutkan apa yang sudah terlebih dahulu ada.

Upaya-upaya perubahan yang ingin dilakukan oleh manajemen yang baru ditempatkan di redaksi SDB terbentur pada keengganan anggota redaksi untuk berubah. Peneliti juga menemukan sejumlah kebiasaan yang telah menjadi rutinitas di dalam redaksi antara lain adalah menerima uang dari narasumber berita, adanya narasumber langganan dan gaya penulisan naskah yang sama. Gaya penulisan naskah berita hasil kerjasama dengan pemerintah daerah ini juga cenderung sama dari waktu ke waktu, lebih menyerupai laporan kegiatan harian kepala daerah daripada sebuah pemaparan isu dan kedalaman data terkait layanan publik masyarakat Sumatera Utara. Tak heran masih cukup banyak masyarakat yang menyaksikan tayangan SDB masih berpersepsi bahwa TVRI merupakan televisi pemerintah karena melaporkan aktivitas harian kepala daerah.
Shoemaker \& Reese (1996: 225) mengatakan bahwa semakin lama seorang jurnalis bekerja pada suatu institusi media mana mereka akan semakin terbiasa dengan kebijakan-kebijakan organisasi baik tertulis ataupun tidak tertulis. Pekerja media belajar dari melihat orang lain, dari tanggapan yang diberikan para senior dan dari bagaimana cara menyelesaikan suatu pekerjaan. Semakin seorang pekerja media bisa menyesuaikan dirinya dengan rutinitas yang ada di organisasinya, maka mereka akan semakin pantas dijadikan rekan kerja yang sepadan.

Terkait dengan berita kerjasama dengan Pemerintah Propinsi Sumatera Utara, tidak ada agenda media khusus atau agenda setting yang diberikan oleh redaksi SDB setiap harinya, melainkan diserahkan pada reporter yang bertugas di lapangan. Salah satu informan bahkan secara rinci menjelaskan akibat adanya perjanjian kerjasama ini terkadang reporter yang bertugas mengesampingkan nilai berita dari aktivitas kepala daerah yang diliput. Seringkali nilai berita dari aktivitas kepala daerah tidak terlalu menonjol namun tetap diliput dan disiarkan.

Walaupun pihak Dinas Komunikasi dan Informatika Propinsi Sumatera Utara sebagai perwakilan Pemerintah Propinsi Sumatera Utara dalam perjanjian kerja sama menyatakan tidak melakukan intervensi kepada reporter TVRI atas isi peliputannya, namun TVRI tetap tidak dapat melepaskan diri dari perjanjian kerjasama tersebut. Artinya, sepanjang TVRI masih tergantung pada pendanaan dari pemerintah yang 
diberikan lewat perjanjian kerjasama penyiaran, isi berita Sumut Dalam Berita tetap akan terpengaruh.

Eva Karin Olsson (2009) dalam penelitiannya membandingkan redaksi tradisional dan redaksi digital. Ia menemukan bahwa redaksi pemberitaan yang telah memiliki rutinitas kerja dan berjalan otomatis di satu sisi akan lebih siap dalam menghadapi berbagai situasi yang harus diliput termasuk situasi krisis sekalipun. Para reporter dan juru kamera sudah berpengalaman dalam menghadapi kasus-kasus peliputan dimana kasus serupa sudah pernah terjadi sebelumnya, sehingga mereka memiliki model dalam pengambilan keputusan. Hal inilah yang menjadi prosedur standar yang berlaku di dalam redaksi, semakin anggota redaksi mengikuti rutinitas di dalam redaksi, semakin mereka bisa memenuhi apa yang diharapkan oleh tujuan redaksi.

Pada tingkatan berikutnya yaitu level organisasi, seluruh informan utama menyatakan bahwa isi Sumut Dalam Berita tidak diintervensi oleh pihak manapun dari dalam organisasiTVRISumateraUtara maupunTVRI secara nasional. Level manajerial termasuk Kepala Stasiun sendiri tidak dibenarkan untuk ikut mempengaruhi isi berita. Hal ini juga bisa dikaitkan dengan bentuk struktur organisasi di TVRI Sumatera Utara terutama redaksi Sumut Dalam Berita yang memiliki beberapa lapisan.

Garis hubungan dalam struktur ini berlaku tegas dimana jalur komunikasi dari Kepala Stasiun dilakukan kepada Kepala Bidang dan Kepala Bidang melakukan komunikasi kepada Kepala Seksi. Tidak banyak forum-forum komunikasi yang membuka ruang secara resmi bagi para reporter dan juru kamera sebagai lapisan terbawah untuk bisa berkomunikasi secara langsung dan intensif dengan puncak pimpinan.

Shoemaker dan Reese (1996: 256) mengungkapkan bahwa semakin banyak lapisan dalam birokrasi antara reporter dan level manajerial maka pihak manajerial akan semakin tidak sensitif terhadap kebutuhan profesional para pekerja di bawahnya. Artinya kondisi ini memungkinkan pihak manajerial kurang mengetahui secara pasti dan rinci permasalahan dan kondisi teknis pekerjadibawahnya.Padahal bilakebutuhankebutuhan individual pada pekerja terpenuhi dengan baik, akan mempengaruhi kualitas kerja secara individual.

Perihal melakukan peliputan dan penulisan berita terutama berita layanan publik oleh pemerintah daerah, jurnalis TVRI Sumatera Utara yang ditugaskan secara sadar sudah mengetahui tugas dan tanggungjawabnya walaupun tanpa perlu diberikan arahan secara terus menerus oleh pihak redaksi, Kepala Seksi, Kepala Bidang atau bahkan Kepala Stasiun. Rutinitas yang sudah berjalan bertahun-tahun membuat mereka sudah tahu bagaimana kemasan berita yang lazimnya disusun untuk disiarkan. Sesuai jumlahnya, maka hasil rekam siar berita layanan publik tersebut akan diberikan kepada pihak pemerintah daerah sebagai bukti dokumentasi.

Tekanan justru datang dari sisi keuangan organisasi yang ternyata mempengaruhi jalannya aktivitas jurnalistik di redaksi Sumut Dalam Berita. Anggaran yang sudah dirancang sejak awal tahun memuat angka yang sudah pasti terkait jumlah berita yang akan 
disiarkan selama satu tahun. Pada prakteknya, keterbatasan anggaran yang berasal dari dana APBN dan non-APBN ini benar-benar dirasakan pada triwulan terakhir dalam setahun. Pihak manajemen redaksi selalu melakukan sejumlah upaya untuk tetap memenuhi durasi siaran SDB walaupun anggaran tidak mencukupi, misalnya menyiarkan berita ringan yang bersifat timeless sehingga dapat diputar berulang-ulang ataupun menyiarkan berita dari stasiun daerah lainnya yang masih berada di Sumatera. Melalui cara ini maka pengeluaran yang seharusnya dibayarkan untuk honor reporter atau kontributor bisa ditekan.

Sumber pemasukan TVRI di tiap daerah untuk non APBN dikelola oleh Seksi Pengembangan Usaha melalui 2 jenis sumber usaha, yaitu Jasa Siaran dan Non Jasa Siaran. Sumber usaha yang merupakan jasa siaran dilakukan dalam bentuk kerjasama siaran iklan dan kerjasama program. Iklan yang masuk ke TVRI bisa berupa iklan komersil maupun iklan layanan masyarakat, yang diterima dengan ketentuan-ketentuan yang disepakati bersama. Sedangkan untuk Non Jasa Siaran, dilakukan dengan beberapa cara, misalnya penyewaan tower pemancar, penyewaan studio, dan penyewaan ruang kerja. Berkaca pada keterbatasan anggaran inilah, maka bentuk kerjasama siaran dengan pemerintah daerah sangat berarti bagi kelancaran operasional TVRI Sumatera Utara.

Kondisi ini jugalah yang menjadi pemicu bagi reporter dan kameramen SDB kerap menerima uang peliputan dari narasumber yang telah mereka liput. Shoemaker dan Reese (1996: 257) mengatakan bahwa bila sebuah organisasi mengalami kondisi ekonomi yang sulit, kebutuhan untuk menghasilkan keuntungan akan lebih unggul bila dibandingkan dengan pertimbangan secara profesional. Tak heran bila kualitas berita layanan publik yang dihasilkan oleh redaksi SDB tidak menjadi fokus utama melainkan memenuhi perjanjian kerjasama untuk melakukan peliputan sesuai jumlah yang sudah ditetapkan.

Terkait dengan level ekstramedia, walaupun secara aturan pihak di luar TVRI tidak dapat mempengaruhi isi Sumut Dalam Berita, namun sesekali masih ada sejumlah pihak eksternal yang belum memahami bahwa TVRI bukan lagi televisi pemerintah. Tak jarang beberapa pihak memposisikan TVRI memiliki kewajiban meliput kegiatankegiatan pemerintahan.

Perjanjian kerjasama antara TVRI Sumatera Utara dengan Pemerintah Kota Medan dan Pemerintah Propinsi Sumatera Utara juga bisa dikaitkan dengan kepentingan ekstramedia terhadap isi berita. Shoemaker \& Reese (1996: 259) menyatakan bahwa walaupun sumber-sumber berita resmi media akan mendominasi isi berita, namun presentasinya akan lebih banyak ditampilkan dari sisi isu daripada peristiwanya. Bertolak belakang dengan yang terjadi di TVRI Sumatera Utara dimana peliputan aktivitas kepala daerah lebih dominan daripada isu publik yang sedang hangat di tataran lokal. Hal ini tentu saja berkaitan dengan aspek perjanjian kerjasama tersebut yang telah ditetapkan jumlahnya.

SDB sebagai bagian dari tayangan TVRI Sumatera Utara sebagai televisi 
publik diharapkan menjadi ruang publik (public sphere) bagi publik Sumatera Utara. Pada dasarnya public sphere merefleksikan bahwa media massa benar-benar menjadi $a$ social institution yang mampu memfasilitasi pembentukan opini dengan menjadi wadah independen untuk perdebatan publik, dimana media tidak terkontrol oleh negara dan pasar (capital owner).

Konsep ini berasal dari pemikiran Jurgen Habermas tahun 1962. Ia memunculkan apa yang disebutnya sebagai 'institutional criteria' yang dimaksudkan untuk memperjelas konsep ruang publik (Nasrullah, 2012: 35-36). Kriteria yang pertama adalah pengabaian terhadap status (disregard of status) atau lebih tepatnya menjauhi diskusi kritis tentang status. Ruang publik tidak memperkarakan keinginan persamaan status dengan otoritas yang berkuasa, tetapi adanya kesempatan yang sama dalam mengungkapkan atau mengkritisi sebuah realitas. Kriteria kedua adalah fokus pada domain of common concern. Realitas historis menunjukkan bahwa beberapa domain hanya dikuasai penafsirannya oleh otoritas yang berkuasa dan atau oleh kalangan gereja. Padahal domain tersebut bisa dibincangkan dengan melibatkan publik secara lebih luas. Kriteria terakhir adalah inklusif (inclusivity). Betapa pun ekslusifnya publik dalam kasus tertentu akan tetapi dalam ruang publik ia menjadi bagian dari kelompok kecil tersebut. Ide-ide yang muncul dari perdebatan khusus mereka pada dasarnya bukan menjadi milik mutlak anggota ruang publik, melainkan ketika disebarkan melalui media maka publik dapat pula mengaksesnya.
Level terluar yang dapat menentukan isi berita adalah faktor ideologi. Seluruh informan utama merujuk pada regulasi yang mengatur aktivitas penyiaran dan jurnalistik sebagai pedoman, yaitu Undang-Undang No 32 Tahun 2002 dan Pedoman Perilaku Penyiaran dan Standar Program Siaran (P3SPS). Kebijakan yang sama juga berlaku pada redaksi Sumut Dalam Berita yang mengadopsi P3SPS yang mengatur secara resmi standar siaran yang berkaitan dengan nilai-nilai kesukuan, agama, ras dan antar golongan; nilai dan norma kesopanan dan kesusilaan; etika profesi; kepentingan publik; layanan publik; hak privasi; perlindungan kepada anak; muatan seksual; muatan kekerasan; muatan mistik dan supranatural; prinsip-prinsip jurnalistik; sensor dan lain-lain.

Meskipun secara sadar jurnalis TVRI Sumatera Utara memahami bahwa regulasi dalam penyiaran menjadi pedoman utama dalam menyusun isi siaran SDB, namun konsep ideal tersebut tak mudah dijalankan secara profesional.

\section{Simpulan}

Berita layanan publik merupakan bagian dari kerjasama TVRI Sumatera Utara dengan Pemerintah Propinsi Sumatera Utara dimana TVRI wajib menyiarkan aktivitas kerja pemerintah daerah dengan kompensasi tertentu yang dibayarkan pertahun. Kerjasama ini merupakan bentuk komitmen TVRI sebagai lembaga penyiaran publik untuk menyiarkan hasil-hasil pembangunan, menjadi penyeimbang dan evaluasi jujur kinerja pemerintah sekaligus membantu TVRI dari aspek pendanaan. Pengolahan naskah dan gambar menjadi kunci utama agar kegiatan 
yang mayoritas adalah seremonial tersebut bisa menarik dan mengena pada kebutuhan khalayak akan informasi kepublikan. Namun dalam prakteknya, hasil berita layanan publik yang ditayangkan masih terasa 'kering' dan terkesan hanya melaporkan kegiatan kepala daerah, tidak ada eksplorasi mendalam akan permasalahan layanan publik serta belum memanfaatkan kesempatan bertemu langsung dengan pemerintah daerah untuk menjawab permasalahan-permasalahan layanan publik yang dibutuhkan masyarakat.

Sejumlah hal dapat dilihat sebagai faktor yang mempengaruhi isi berita yang disusun oleh redaksi Sumut Dalam Berita (SDB), mulai dari level individual hingga level ideologi. Masih ditemukan beberapa kelemahanyangmembuatredaksiSDBbelum dapat maksimal dalam menjalankan aktivitas jurnalistiknya sesuai regulasi yang berlaku. Selain kompetensi para jurnalisnya secara individual, redaksi SDB memiliki rutinitas kerja yang sudah berlangsung bertahuntahun dan membentuk kebiasaan dalam gaya jurnalistik seperti dalam hal penentuan nilai berita dan pemilihan narasumber. Nilai berita acapkali dikesampingkan hanya untuk memenuhi jumlah berita yang disepakati bersama pemerintah daerah.

Keterbatasan anggaran menjadi faktor internal organisasi TVRI Sumatera Utara yang cukup menentukan isi siaran SDB. Redaksi dan jurnalis TVRI Sumatera Utara melakukan sejumlah upaya untuk menutupi kekurangan anggaran dengan cara-cara yang bahkan sangat mungkin mempengaruhi independensi jurnalistik. Hal ini jugalah yang membuat dana dari pemerintah daerah melalui kerjasama siaran menjadi penting bagi operasional TVRI Sumatera Utara.

Merujuk pada limatingkatan pengaruh isi media Shoemaker dan Reese, jurnalis TVRI Sumatera Utara pada dasarnya memiliki pengetahuan akan konsep ideal dalam menjalankan aktivitas jurnalistiknya namun dalam pelaksanaannya terjadi tumpang tindih antara idealisme dan aspek praktis. Faktor-faktor inilah yang membentuk isi tayangan SDB setiap harinya.

Sebagai implementasi penelitian ini, dapat dilakukan pembenahan dalam redaksi Sumut Dalam Berita dalam hal sistem kerja dan kualitas sumber daya manusia, terutama penyegaran kembali pemahaman akan konsep penyiaran publik yang bertujuan melayani publik Sumatera Utara dengan informasiinformasi berkualitas. Sebagai saran bagi penelitian selanjutnya menarik bila dilakukan kajian lebih jauh mengenai proses internalisasi rutinitas dan budaya organisasi media pada anggota redaksi pemberitaan.

\section{Daftar Pustaka}

Lembaga Penyiaran Publik Televisi Republik Indonesia. (2012). Transformasi TVRI Kebijakan LPP TVRI Tahun 2011-2016. Jakarta : TVRI

Moleong, L. J. (2006) Metodologi Penelitian Kualitatif (Edisi Revisi). Bandung: PT Remaja Rosdakarya

McQuail, D. (2010). Mass Communication Theory $6^{\text {th }}$ Edition. London: SAGE Publications Ltd

Nasrullah, R. (2012). Internet dan Ruang Publik Virtual : Sebuah Refleksi atas Teori Ruang Publik Habermas dalam Jurnal Komunikator Vol 4, No 1 Tahun 2012. 26-35 
Olsson, E. (2009). Media Crisis Management in Traditional and Digital Newsrooms. Convergence : The International Journal of Research into New Media Technologies Vol 15(4): 446-461

Peraturan Dewan Pers Nomor 1/PeraturanDP/II/2010 Tentang Standar Kompetensi Wartawan

Riset Penonton dan Program TVRI Sumatera Utara 2013 oleh Tim Peneliti Departemen Ilmu Komunikasi USU

Shoemaker, P. J. \& Reese, S. D. (1996). Mediating the Message : Theories of Influences on Mass Media Content. New York: Longman Publishers

Survei Indeks Kualitas Program Siaran Televisi Periode November-Desember 2015. Diakses 17 Februari 2016 dari http://kpi.go.id/download/ Pengumuman/
Handout-hasil-survei-indeks-kualitasprogram-siaran-televisi-NovemberDecember-2015.pdf

Undang-undang No 25 Tahun 2009 tentang Pelayanan Publik

Undang-undang No 32 Tahun 2002 tentang Penyiaran

United Nations Development Programs Bureau for Development Policy. (2004). Public Service Broadcasting. Paper for Supporting Public Service Broadcasting, Learning from Bosnia and Herzegovina's Experience

Weeds, H. (2013). Digitalisation, Programme Quality and Public Service Broadcasting. Is There Still a Place for Public Service Television: Effects of the Changing Economics of Broadcasting. Reuters Institute for the Study of Journalism at the University of Oxford 